\title{
BUKHARA GUZARS AND THEIR ROLE IN THE SOCIO-ECONOMIC LIFE OF THE CITY
}

\section{T.T. Safarov}

Associate Professor Department Of Social And Humanitarian Physical Culture And Sports Tashkent Institute Of Irrigation And Agricultural Mechanization Engineers Bukhara Branch, Uzbekistan

\section{ABSTRACT}

This article provides information about the guzars created by the dynasties that ruled the city of Bukhara in different historical periods and their place and role in social life. It is known from history that all cities go through a period of development or crisis. While a certain historical situation led to the expansion of the urban area, various invasions served to turn it into a ruin. Of course, history has shown that this fate has not escaped our beloved city.

KEYWORDS: - The market counter, the cotton market, trade, the caravanserai, caravan leader.

\section{INTRODUCTION}

Ancient and eternally young Bukhara has a rich history, and for centuries the representatives of various dynasties who ruled here have built buildings and structures of social significance of the city. In order to gain a broader knowledge of the history of ancient Bukhara, it is important to know the processes of formation of its settlements. Especially as a result of the transformation of the Emirate of Bukhara into a vassal by the Russian Empire, the interest of Russian orientalists and historians in Bukhara and its history has finally increased. In this regard, the scientific research of well-known Russian historians L.I. Rempel and O.A. Sukhareva is noteworthy.

A special feature of O.A. Sukhareva's research is that it provides information about each guzar. L.I. Rempel, on the other hand, focuses on generalizing the history of the Bukhara guzars in a new interpretation, that is, according to the nature of their formation. It is known from history that all cities go through a period of development or crisis. While a certain historical situation led to the expansion of the urban area, various invasions served to turn it into a ruin. of course, history has shown that this fate has not escaped our beloved city. According to academician A.Muhammadjanov, the area of Bukhara is four hectares. The expansion of the urban area also affected the number of guzars. That is why we come across different numbers in the sources on the number of guzars. In particular, in the works of Russian orientalists A.Kun and L.I.Rempel it is noted that in Bukhara in the XIX century there were 197 guzars. G.Yu.Astanova informs that the city of Bukhara has 200 guzars, which have 25 thousand yards, and the population is about 60-70 thousand.

\section{THE MAIN FINDINGS AND RESULTS}


CURRENT RESEARCH JOURNAL OF HISTORY 2(11): 13-17, November

2021

DOI: https://doi.org/10.37547/history-crjh-02-11-04

ISSN 2767-472X

(C2021 Master Journals

Crossref do

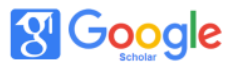

Accepted 08 ${ }^{\text {th }}$ November, 2021 \& Published $13^{\text {th }}$ November, 2021

If we pay attention to the names of Bukhara guzars, such factors as the occupation of the population, the climate of the area, geographical location, structure played a decisive role in their formation. In particular, Sozangaron, Kulolon, Harroton, Pukhtabofon, Zargaron, Charmgaron, Urgenchiyon, Sarakhsiyon, Uruson, Chakari Joybor, Havzi Nav, Kuchai Bodom, Chukur district, Hammomi kappa, Hammomi kunjak, Eshoni imlo, Machiti baland, Miri arab, Goziyon, Domullo Sher, Khoja Zoyid, Khoja Zayniddin are a confirmation of our above-mentioned comments. In the internal structure of the city of Bukhara, in addition to the guzar, there are also geographical divisions, and such places are called districts. There can be several guzars in one area. The sources provide information about the districts of Bukhara, such as Sheikh Rangrez, Turki Jandi, Joybor, Chashmai Ayyub, Registan, Khiyabon, Murdashoyan, Sufiyon, Gavkushan, Shahristan, Iskandarkhan, Kalabad, each of which has a rich history.

We have seen below the need to reflect on the history of the emergence of some guzars, their place in the social life of the city. One of such guzars is Sheikh Rangrez guzar, which was built in the middle of the XV century. According to "Mullozoda's book", in ancient times he was a master of flowers in Bukhara. It gave beautiful dyes to the fabrics. After the master's death, the faithful disciples built a mosque in his honor and immortalized his name. This guzar is located in front of the Karshi or Qavola gate in the city. It is known that the Karshi Gate connected the city with the railway, so the place was crowded with people. From here it was possible to buy everything you needed for the household. The same place was the center of the Rangrez guzar, where there was a mosque, a madrasa and a swimming pool. The inhabitants of Guzar were mainly engaged in dyeing, but also made karakul skins, from which they made beautiful, elegant, inexpensive clothes, which became famous in seven climates. Guzar occupied a large area. Next to it was a mausoleum, where the tombs of Shaykh al-Alam, that is, Sayfiddin Bokharzi, were located. After the October coup, the policy of the dictatorial regime led to a change in the image of the Guzars. When the guzars were reenumerated in 1929, Sheikh Rangrez renamed the guzar Mirza Rabi. The Arab is one of the ancient guzars of the city of Bukhara, and there is information that it belongs to the XV century. This guzar is located on the side of the road near the Sallakhona Gate, and the majority of its population is Arab. The main occupation of the population was Karakul leather. There is an Arabon mosque in Guzar, which is distinguished by its ancient building architecture. It is noteworthy that famous traders, such as Yusufbek Jurabek, who traded in Karakul leather, especially with Russian traders, lived in this guzar.

According to historical sources, the Arab Guzar was close to the Sallakhana Gate, so during the construction of the Bukhara Fortress in the second half of the XVI century, the Guzar people, who closely assisted in the construction of the fortress, provided material support. Even today, this guzar is called Arabon. It is located on the street that leads to Mount Sarrafon, where generations of Arabs still live. Another ancient guzar of Bukhara is named after Muhammad Qasim, which was founded in the 80s of the XV century. Here the mosque was named after the person who built it, Guzar, and the population was engaged in small handicrafts, attar and farming. Among the guzars in Bukhara, the guzar of Caliph Hussein has a special significance, it was built in the XVII century. The population of Guzar was mainly engaged in small crafts. As there were rastas on both sides of the Guzar road, part of the population made a living by trading. Here is the center of the Sufis, the room 
CURRENT RESEARCH JOURNAL OF HISTORY 2(11): 13-17, November

2021

DOI: https://doi.org/10.37547/history-crjh-02-11-04

ISSN 2767-472X

(C2021 Master Journals

\section{Crossref doi) 80 Google}

Accepted 08 ${ }^{\text {th }}$ November, 2021 \& Published $13^{\text {th }}$ November, 2021

of Caliph Hussein. There was a swimming pool and a cemetery named after Caliph Hussein in addition to the school. At present, this guzar has not been preserved.

The Mir Masud guzar was formed at the end of the XVII century at the same time as the Sallakhona Gate. Some of the locals were craftsmen and some were bakers. In Guzar, a number of wealthy people were engaged in trade, including Turakulboy, who had a high reputation and mainly bought leather goods for the CIS countries, from which he brought household goods and traded them in the city markets. A two-story madrasa was built by him, but because there was no school, the children were educated in a school in the Arabian guzar. The Khojabulgor guzar was founded by Amir Shahmurad, one of the representatives of the Mangit clan of Bukhara, who ruled in the last quarter of the XVIII century. Guzar was inhabited by people of various professions, including alocha, adras weavers, as well as bootmaker. A certain part of the population was also engaged in pottery. Sources say that Guzar had a mosque, a madrasa-school, a swimming pool, and even a separate school for girls. One of the attractions of Guzar is the tomb of Khojabulgor. It is said that the son of the Bulgar king quarreled with his father, lived in the guzar chillakhana, and died there. Today, most of these streets have been preserved, and the ancient name has been restored and renamed Khojabulgor. Another ancient guzar of the city of Bukhara is called Kokilai Kalon, and it is noted in the foundation documents that it was registered in the XVII century. It was inhabited mainly by merchants, who had shops in the towns and villages of the city. In Guzar, there was a mosque, school and madrasa built by Abdujafarkhoja Bay. At the head of this closed street live telpak-tailors, who still cherish the craft of their ancestors. The Lower Murgkush guzar dates back to the late XVI and early XVII centuries and was only recorded in foundation documents in the early XVIII century. Guzar was bordered by Khojabulgor and Khullabofon guzars, and a famous caravan leader, Ahmadbay, who traded with Russia, lived here. It is noteworthy that the mosque and school in Guzar had a women's bath named after Khodja Porso. At the initiative of Khodja Porso, when the construction of the bath was completed, the chicken was slaughtered and blood was drawn, and as a result, the guzar was renamed Lower Murgkush.

In the 80s of the XVIII century in Bukhara there was a guzar called Chor caravanserai, the big caravanserai of which was named after the famous merchant Rashidbek. In this caravanserai, traders from Afghanistan were engaged in trade. One of the important aspects of Guzar is that the Sarrofon Taki is located here, where the money of traders from different countries was exchanged by money changers. There is also a Sarrofon bath here, which, although it is a men's bath, serves women two days a week.

Today, this place is one of the favorite destinations of foreign and local visitors. One of the oldest guzars in Bukhara is called Turki Jandi, and there is a tomb here, according to the "Mullozoda Book". According to the information, this tomb is the tomb of Musa Jand, who lived in the XX century, and he was a student of Abu Bakr ibn Is'haq Kalabadi. In Guzar, the population was sparse and lived mainly on small crafts. One of the guzars built in the XV century was called Ghazian, and most of its population was made up of merchants. Silk and adras weavers also lived in this guzar. Sources say that people like Nasir Bay and Sadriddin Bay lived in Guzar. It is known from history that the Gazis fought for the true religion, which is why Bukhara was the center of the Muslim community. 
CURRENT RESEARCH JOURNAL OF HISTORY 2(11): 13-17, November

2021

DOI: https://doi.org/10.37547/history-crjh-02-11-04

ISSN 2767-472X

(C2021 Master Journals

Crossref do

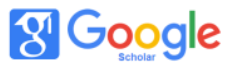

Accepted 08 ${ }^{\text {th }}$ November, 2021 \& Published $13^{\text {th }}$ November, 2021

It is noteworthy that there are many madrassas here, the largest of which is the Mullah Muhammad Sharif Madrassa. The fact that the famous writer Sadriddin Aini studied at this madrasah is a proof that his prestige is much higher than other madrasas. The guzar named after Sheikh Jalal, one of the famous guzars of its time, was founded in the late XVI century. The people who lived here were mainly engaged in weaving, and the products produced by them were mainly sold in the domestic markets. There is a mosque and a school in Guzar, and in the tomb at the back of the mosque is the tomb of Sheikh Jalal, one of the rulers of the Bukhara Khanate, known as the Piri of Abdulaziz Khan. This information was put forward in the book "History of Mir Haydar". Another important aspect of this tomb is that children with whooping cough were treated by drinking water from a blue bowl. Another of the most famous guzars of Bukhara is Postindozon. This guzar was formed in 1832-1833. Guzar is called by this name because the main occupation of the population was skinning. In addition, the guzar was inhabited by people who made a living by adrasbof, attor, and trade. One of the most influential and famous rich people of Guzar was Toshanboy, who had a cotton factory in Chorjoi and a large caravanserai in Merv. Now these lands are the neighborhoods to the left of Taqi Sarrofon. In addition to the interesting information about the period we are considering, it is important to note that Bukhara was not named Sharif for nothing. Indeed, the graves of more than seven thousand saints are located in and around Bukhara. Below we share some of our thoughts on some of the guzars in Bukhara and the shrines located there.

It is known that the tomb and tomb of Qasimi Sheikh were in Karmana, and when he came to Bukhara during the reign of Abdullah Khan, this guzar was named after him as his sacred shrine.
The question arises, why was this person elevated by the ruler? We studied the sources and became convinced that when Abdullah came to power, a number of provinces would disobey him and even declare war on him. As a result, he pays homage to the sheikh's soul and asks for his help, and as a result, his authority will be stable in a short time. This is probably why almost all the rulers in history were honored by their pirs. In 1929, the guzars of Tagmandbofon and Qasimi Sheikh were united and renamed Mirza Usman. Now this street is located behind the old farmers' market. The enterprise guzar is on the left side of Samarkand street, where there are many monuments. Guzar leads to Khoja Nurabad cemetery from the north and south. According to the legends, Khoja Nurabad, Khoja Sesaron, Khoja Aspgardon were brothers. Although all three cemeteries are among the oldest cemeteries in the city, according to some legends, they were considered shrines before the advent of Islam. The population of Guzar was mainly engaged in textiles and handicrafts.

In front of the gate of Hazrat Imam of the city is the guzar of John Kubad, and there is the tomb of a saint carrying the coffins of Imam Hussein. There is no exact information about this in the sources. The second shrine in this guzar is the tomb and tomb of Shukurbek, which was built during the reign of Amir Nasrullo. Ahmad Donish in his work "Navodir ul vakoe", S. Ayni's "Memories" and other works wrote detailed information about this shrine. The guzar of Mawlana Sharif was named after Hazrat Sheikh Mawlana Sharif, who was unique in the external and internal sciences. Akhund of Uzot Kukaldosh Madrasa, who had a deep knowledge of Fiqh (Islamic jurisprudence), was considered one of the great mashayiks of his time. He also had the ability to know future events. In this article, we have provided information about some guzars who have left a significant mark on the history of 
DOI: https://doi.org/10.37547/history-crjh-02-11-04

ISSN 2767-472X

(C)2021 Master Journals

\section{Crossref dol 8 Google}

Accepted 08 ${ }^{\text {th }}$ November, 2021 \& Published $13^{\text {th }}$ November, 2021

Bukhara, witnessed significant events in the economic, political and social life of the city.

\section{Conclusion}

After the abolition of the Emirate of Bukhara by the dictatorial Soviet regime, the Guzars, which had long been the center of culture and enlightenment, were re-registered, and as a result of chauvinistic policies, almost all Guzars were given names of other nationalities. This marked the beginning of a comprehensive political process aimed at depriving us of our identity, which is the subject of a separate article. Only national independence has served as a basis for the realization of the age-old dreams and hopes of our people and the restoration of historical truth. The large-scale beautification and creative work carried out in our country today is radically changing the appearance of villages and districts. In particular, the creative work carried out in the ancient and eternally young city of Bukhara, and its main goal is to increase the welfare of the population, and secondly, to create favorable conditions for foreign tourists to enjoy their leisure time, thereby turning Bukhara into a tourist crossroads. it is our most noble goal to glorify its history to the world. In our next articles we will provide information about other guzars of our native Bukhara, their place and role in our history, social relations of the population.

\section{REFERENCES}

1. Rempel L.I. Bukhara records. Toshkent,1981, P. 304.

2. Rakhmatova S., H.Qurbonov. Excerpts from the history of Bukhara guzars. Bukhara :1995, P. 143.

3. Mukhammadzhonov A.R. Irrigation history of

the Bukhara oasis. Tashkent: 1978, P. 291.

4. Sukhareva O. Quarter community of the late feudal city of Bukhara. Moscow: 1976, P. 247. 